\title{
Kualitas Pelayanan Administrasi Kepegawaian Dinas Pendidikan Provinsi Sumatera Selatan
}

\author{
Mardesah \\ Universitas Bina Darma \\ Email:mardesah_se@yahoo.co.id \\ Rabin Ibnu Zainal \\ Universitas Sumatera Selatan \\ Email: rabin@uss.ac.id
}

\begin{abstract}
This study aims to determine the assessment of the quality of administration staff services at the Education Office of South Sumatra Province (Dinas Pendidikan Provinsi Sumatera Selatan) based on the analysis results of five dimensions of service quality in the SERVQUAL (service quality) model, named Tangible (Physical Evidence), Empathy (Care), Realibility, Responsiveness (Quick Response) and Assurance (Certainty). The collected data was analyzed using a questionnaire in the form of a SERVQUAL scale that describes the gap (GAP) of the expected service quality between expectations and reality (perceptions) received by the Educators and Education Personnel of the South Sumatra Province Education Office. The results of the study indicate that the quality of personnel administration services has not been a satisfactory because of the dimensions that have a minus or negative value, named: Realibility -0.15 and Responsiveness -0.46 . Therefore, the South Sumatra Provincial Education Office(Dinas Pendidikan Provinsi Sumatera Selatan) needs to improve the quality of administrative services so that it is optimal and changes the gap to a positive value. Recommendations for improvement are made using the Fishbone Diagram and the Kaizen 5W $1 \mathrm{H}$ method. The fishbone chart is useful for showing the main factors that affect quality and have an impact on service quality. If the problems and causes are known for certain, then the corrective actions and steps will be easier to conduct. To create a Fishbone Diagram, the Kaizen Method Tools are used by asking several questions on the basis of $5 \mathrm{~W}+1 \mathrm{H}$ (what, who, why, where, when and How).
\end{abstract}

Keywords: SERVQUAL, GAP analysis, Administrative Services

Abstrak
Penelitian ini bertujuan untuk mengetahui penilaian kualitas pelayanan administrasi kepegawaian Dinas Pendidikan Provinsi Sumatera Selatan didasarkan pada hasil analisa lima dimensi kualitas jasa dalam model SERVQUAL (service quality) yaitu Tangible (Bukti Fisik), Emphaty (Kepedulian), Realibility (Keandalan), Responsiveness (Keandalan/Cepat Tanggap) dan Assurance (Kepastian). Data yang terkumpul dianalisa menggunakan kuesioner berupa skala SERVQUAL yang menggambarkan kesenjangan (GAP) kualitas pelayanan yang diharapkan antara (ekpetasi) dan kenyataan (persepsi) yang diterima oleh Tenaga Pendidik dan Tenaga Kependidikan Dinas Pendidikan Provinsi Sumatera Selatan. Hasil penelitian menunjukkan bahwa kualitas pelayanan administrasi kepegawaian belum memuaskan karena ada dimensi yang bernilai minus atau negative yaitu : Realibility -0,15 dan Responsiveness -0,46. Oleh karena itu Dinas Pendidikan Provinsi Sumatera Selatan perlu meningkatkan kualitas pelayanan administrasi agar optimal dan merubah Gap menjadi bernilai positif. Rekomendasi perbaikan dilakukan dengan Diagram Fishbone dan Metode Kaizen 5W 1 H. Diagram tulang ikan (fishbone chart) berguna untuk memperlihatkan faktor-faktor utama yang berpengaruh pada kualitas dan mempunyai akibat pada kualitas pelayanan. Apabila masalah dan penyebab sudah diketahui secara pasti, maka tindakan dan langkah perbaikan akan lebih mudah dilakukan. Untuk membuat Diagram Fishbone digunakan Tools Metode Kaizen yaitu dengan teknik bertanya dengan pertanyaan, dengan dasar $5 \mathrm{~W}+1 \mathrm{H}$ yaitu what, who, why, where, when dan who.

Kata Kunci: SERVQUAL, GAP analysis, Pelayanan Administrasi.

\section{Pendahuluan}

Sesuai Lampiran UU RI Nomor 23 Tahun 2014 Tentang Pemerintah Daerah terjadi pengalihan wewenang pengelolaan Pengelolaan Pendidikan Menengah dan Pengelolaan Pendidikan Khusus yang sebelumnya dikelola oleh Pemerintah Kabupaten Kota ke Pemerintah Provinsi Sumatera Selatan. 
Dengan beralihnya kewenangan Pengelolaan Pendidikan Menengah dan Pengelolaan Pendidikan Khusus ke Dinas Pendidikan provinsi Sumatera Selatan sebagai salah satu Organisasi Perangkat Daerah (OPD) di Pemerintah Provinsi Sumatera Selatan maka status Aparatur Sipil Negara (ASN) Pemerintah kabupaten kota berubah status menjadi ASN di lingkungan Dinas Pendidikan Provinsi Sumatera Selatan. Pergub Sumatera Selatan nomor 52 Tahun 2016 Pasal 7 ayat 3 huruf a angka 3 Subbagian Umum dan Kepegawaian mempunyai tugas : Menyelenggarakan administrasi kepegawaian yang meliputi pendataan, analisis, pemetaan dan penyajian data pegawai, analisis jabatan dan beban kerja, mutasi, kenaikan pangkat, kenaikan gaji berkala, cuti, pensiun, pemberian penghargaan dan pengelolaan pegawai honorer.

Terdapat beberapa permasalahan yang dihadapi oleh staf Umum dan Kepegawaian Dinas Pendidikan Provinsi Sumatera Selatan dalam memberikan pelayanan kepada Tenaga Pendidik dan Kependidikan. Para Tenaga Pendidik dan Tenaga Kependidikan yang berasal dari 17 Kabupaten Kota harus menempuh jarak yang cukup jauh untuk mencapai lokasi Dinas Pendidikan Provinsi Sumatera Selatan tentu ingin mengurus layanan dengan cepat. Tetapi yang terjadi di Lapangan justru kadang tidak sesuai dengan harapan mereka. Misalnya ketika mereka tiba di lokasi untuk mengurus salah satu administrasi kepegawaian yang mereka butuhkan terkadang petugas di Bagian Umum dan Kepegawaian tidak ada ditempat. Mereka harus menunggu cukup lama, dan ketika bertemu pun ternyata berkas yang mereka bawah kurang lengkap. Sebagian Tenaga Pendidik baru mengetahui syarat - syarat administrasi yang harus dilengkapi ketika sampai di Dinas Pendidikan Provinsi Sumatera Selatan walaupun bagian Umum dan Kepegawaian sudah mengumumkan syarat-syarat administrasi kepegawaian yang harus dilengkapi melalui surat edaran ke sekolah.

Aturan Birokrasi juga membuat layanan administrasi kepegawaian tidak bisa dapat diselesaikan dalam satu hari. Tentu saja para pendidik dan tenaga kependidikan harus kembali datang ketika akan mengambil dukumen administrasi kepegawaian yang mereka urus. Tentu saja hal ini menambah biaya tranportasi dan akomodasi yang cukup besar. Masalah ini kadang membuat mereka malas untuk berurusan ke Dinas Pendidikan Provinsi Sumatera Selatan. Oleh sebab itu ada diantara mereka yang terbengkalai dalam beberapa urusan administrasi kepegawaian seperti kenaikan pangkat, gaji berkala dan izin belajar karena merasa malas atau merasa akan kesulitan untuk mengurusnya ke Dinas Pendidikan Provinsi Sumatera Selatan. Adanya perbedaan antara harapan dengan persepsi yang dialami oleh para Tenaga Pendidik dan Tenaga Kependidikan menimbulkan kesenjangan atau GAP pada Kualitas Pelayanan Administrasi di Dinas Pendidikan Provinsi Sumatera Selatan.

\section{Literature Review}

2.1 Pelayanan Publik

Istilah pelayanan dalam bahasa Inggris adalah "service". A.S.Moenir, 2002 (Nurdin, 2019) mendefinisikan "pelayanan sebagai kegiatan yang dilakukan oleh seseorang atau sekelompok orang dengan landasan tertentu dimana tingkat pemuasannya hanya dapat dirasakan oleh orang yang melayani atau dilayani, tergantung kepada kemampuan penyedia jasa dalam memenuhi harapan dari pengguna. Serangkaian dari kegiatan yang merupakan proses dari pelayanan yang berlangsung secara rutin dan terus menerus atau berkesinambungan adalah hakikat dari pelayanan."

Dinas Pendidikan Provinsi Sumatera Selatan adalah organisasi publik yang wajib memberikan pelayanan prima kepada para pengguna layanan. Tjiptono, 1996 (Rodiyah, 2014) mengemukakan ada empat unsur pokok yang terkandung di dalam pelayanan yang prima (service excellence), yaitu kecepatan, ketepatan, keramahan dan kenyamanan. Keempat komponen itu merupakan satu kesatuan yang terintegrasi, dalam arti jika ada salah satu komponen yang kurang, maka pelayanan tidak akan. Pada umumnya pelanggan menginginkan produk jasa layanan yang memiliki karakteristik lebih cepat, lebih murah dan lebih baik. Dengan demikian perlu diperhatikan dimensi waktu, dimensi biaya, maupun dimensi kualitas baik produk maupun kualitas sikap. Pelayanan yang terbaik adalah melayani setiap saat, secara cepat dan memuaskan, berlaku sopan, ramah dan menolong serta professional. Di 
dalam Organisasi Pemerintah, Pelayanan kepada masyarakat Aparatur Sipil Negawa wajib memberikan pelayanan Prima. Membicarakan pelayanan prima (excellent service/service excellence) sebenarnya merupakan bagian dari perbincangan seputar kualitas pelayanan. (Semil: 2018).

Selanjutnya menurut Kotler dalam Rodiyah (2014) terdapat lima dimensi ServQual (Service Quality) yang dipakai untuk mengukur kualitas pelayanan, yaitu :

a. Tangibles, bukti fisik

Kemampuan suatu perusahaan menunjukan eksistensinya kepada pihak eksternal. Penampilan dan kemampuan sarana dan prasarana fisik perusahaan dan keadaaan lingkungan sekitarnya adalah bukti nyata dari pelayanan yang diberikan oleh pemberi jasa.

b. Realibility, keandalan

Kemampuan perusahaan memberikan pelayanan sesuai yang dijanjikan secara akurat dan terpercaya.

c. Responsiveness, ketanggapan

Suatu kemauan memberikan dan memberikan pelayanan yang cepat (responsive) dan tepat kepada pelanggan dengan penyampaian informasi yang jelas.

d. Assurance, Jaminan dan kepastian

Pengetahuan, kesopansantunan dan kemampuan para pegawai perusahaan untuk menumbuhkan rasa percaya para pelanggan kepada perusahaan

e. Emphaty, perhatian,

Memberikan perhatian yang tulus dan bersifat individual atau pribadi, diberikan kepada para pelanggan atau konsumen dengan berupaya memahami keinginan konsumen".

\subsection{Analisis SERVQUAL}

Model Kualitas layanan yang paling populer dan hingga kini banyak dijadikan acuan dalam riset manajemen dan pemasaran jasa adalah model SERVQUAL (singkatan dari service quality) yang dikembangkan oleh Parasuraman, Zeithaml, dan Berry (1985, 1988, 1991, 1993, 1994) dalam Tjiptono (2017) menyatakan serangkaian penelitian mereka terhadap enam sektor jasa: reparasi peralatan rumah tangga, kartu kredit, asuransi, sambungan telepon interlokal, perbankan ritel, dan pialang sekuritas. Model yang dikenal pula dengan istilah GAP Analysis Model ini berkaitan erat dengan model kepuasan pelanggan yang didasarkan pada ancangan diskonfirmasi (Oliver dalam Tjiptono, 2017). Ancangan ini menegaskan bahwa bila kinerja pada sebuah atribut (Atrtribute performance) lebih besar daripada ekspetasi (Expectations) atas atribut besangkutan, maka persepsi terhadap kualitas layanan akan positif dan sebaliknya.

Gambar 1. Kerangka Pemikiran

KUALITAS PELAYANAN

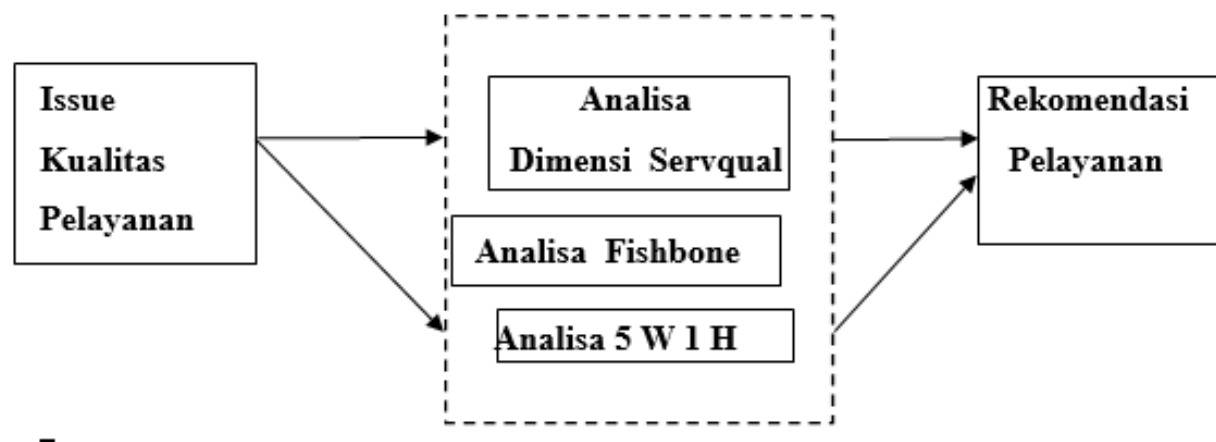

Sumber : Penulis, Data Diolah

\section{Metodologi Penelitian}


Metode penelitian yang diambil adalah dengan cara Deskriptif Kuantitatif model SERVQUAL melalui 5 dimensi kualitas jasa yang dipersepsikan oleh Tenaga Pendidik dan Tenaga Kependidikan melalui jawaban-jawaban yang disampaikan dalam kuesioner. Penelitian ini dilakukan di Dinas Pendidikan Provinsi Sumatera Selatan untuk mengetahui kualitas pelayanan administrasi kepegawaian di Dinas Pendidikan Provinsi Sumatera Selatan

Penelitian ini menggunakan penelitian kuantitatif. Menurut Sugiyono (2012:11) penelitian kuantitatif dapat diartikan sebagai metode penelitian yang berlandaskan pada filsafat positivisme. Metode ini digunakan untuk meneliti pada populasi atau sampel tertentu, pengumpulan data menggunakan instrumen penelitian berupa kuesioner. Penulis menggunakan metode penelitian Deskriptip Kuantitatif, yaitu "menganalisa data yang diperoleh melalui penyebaran kuesioner dengan cara mendeskriptipkan atau memaparkan berdasarkan fakta yang ada dan sedang terjadi dengan diterapkan pada teori yang berkaitan dengan permasalahan yang diangkat dalam judul penelitian ini. Penelitian dilakukan dari Bulan Februari 2021. Dalam penelitian ini yang menjadi populasi adalah seluruh Pendidik dan Tenaga kependidikan yang berjumlah 9196 orang (sumber : renstra 2019-2024) di Lingkungan Dinas Pendidikan Provinsi Sumatera Selatan. Rumus yang digunakan untuk menentukan jumlah sampel adalah rumus sloven yaitu :

$$
\mathrm{n}=\frac{\mathrm{N}}{1+\mathrm{N}(\mathrm{e})^{2}}
$$

Keterangan:

$\mathrm{n}=$ Sampel

$\mathrm{N}=$ Populasi

$\mathrm{e}=$ Tingkat kesalahan

Dengan margin error ditentukan $10 \%$ maka jumlah sampel :

$\mathrm{n}=\frac{9196}{1+9196(10 \%)^{2}}=\frac{9196}{1+9196(0,01)}=-\frac{9196}{1+91,96}=-\frac{9196}{92,96}=98,93$

Dengan rumus di atas maka diketahui jumlah sampel adalah sebanyak 98,93 atau dibulatkan menjadi 100 orang.

\subsection{Uji Kelayakan Instrumen Penelitian}

\subsubsection{Uji Validitas Angket}

Validitas mengandung makna yang sinonim dengan kata good. Validity dimaksudkan sebagai "to measure what shoud be masured" (Ferdinand, 2014). Dalam penelitian ini, angket akan diuji cobakan kepada 100 Tenaga Pendidik dan Tenaga Kependidikan di Dinas Pendidikan Provinsi Sumatera Selatan. Dalam penelitian ini, instrumen terdiri dari butir-butir pernyataan yang telah tersedia jawabannya (kuesioner/angket tertutup). Skala skor yang dipakai adalah skala likert. Untuk mengukur validitas angket dilakukan dengan menggunakan rumus korelasi product moment. Uji validitas secara teknis akan dilakukan dengan menggunakan program SPSS.

Hasil penghitungan masing-masing butir pernyataan akan dibandingan dengan nilai kritis pada $r_{\text {tabel }}$ product moment dengan kriteria sebagai berikut.

a. $\quad$ jika $r_{\text {hitung }}>r_{\text {tabel }}$ maka data tersebut valid

b. $\quad$ jika $r_{\text {hitung }} \leq r_{\text {tabel }}$ maka data tersebut tidak valid 


\subsubsection{Uji Reliabilitas}

Reliabilitas menunjukkan scale atau instrumen pengukur data dan data yang dihasilkan disebut reliable atau terpercaya apabila intrumen itu secara konsisten memunculkan hasil yang sama setiap kali dilakukan pengukuran (Augusty Ferdinand, 2014). Suatu tes dikatakan reliabel apabila tes tersebut mempunyai ketepatan hasil, artinya jika dikenakan pada objek yang sama pada lain waktu hasilnya tetap. Uji reliabilitas dilakukan dengan bantuan program SPSS. Hasil penghitungan uji reliabilitas dibandingkan dengan $r_{\text {tabel }}$ product moment dengan kriteria sebagai berikut.

a) Jika $r_{\text {hitung }}>r_{\text {tabel }}$ maka data tersebut reliabel

b) jika $r_{\text {hitung }} \leq r_{\text {tabel }}$ maka data tersebut tidak reliabel

\subsubsection{Teknis Analisis Data}

Teknik analisis data yang digunakan adalah :

1. Metode SERVQUAL, yaitu suatu metode untuk mengukur kualitas pelayanan kepegawaian berdasarkan lima dimensi kualitas jasa. Dalam menganalisis data penelitian ini digunakan metode deskriptif kualitatif. Dalam penelitian ini digunakan skala 5 tingkat (Likert) untuk Persepsi dan Harapan Tenaga Pendidik dan Tenaga Kependidikan, yaitu :

- Jawaban sangat Setuju diberi bobot 5.

- Jawaban Setuju diberi bobot 4.

- Jawaban Ragu - Ragu diberi bobot 3.

- Jawaban Tidak Setuju diberi bobot 2.

- Jawaban Sangat Tidak Setuju diberi nilai 1.

Pengolahan data skala Likert akan menggunakan SPSS.

2. Mengidentifikasi dan pengendalian kualitas pelayanan administrasi kepegawaian dengan melalui Analisa Fishbone dan Metode Kaizen $(5 \mathrm{~W}+1 \mathrm{H})$.

\section{Hasil dan Pembahasan}

\subsection{Uji Validasi}

Tabel 1. Tabel Uji Validasi Persepsi Kualitas Layanan Administrasi Pendidikan

\begin{tabular}{|l|l|l|l|l|}
\hline No & \multicolumn{1}{|c|}{ Daftar Pertanyaan } & $\mathrm{r}_{\text {hitung }}$ & $\mathrm{r}_{\text {tabel }}$ & Status \\
\hline 1 & \multicolumn{1}{|c|}{ Kehandalan (Reliability) } & & & \\
\hline 2 & $\begin{array}{l}\text { Staf bagian Umum dan Kepegawaian memiliki kemampuan } \\
\text { memproses usul berkas layanan administrasi anda }\end{array}$ & 0,230 & 0,195 & Valid \\
\hline $\begin{array}{l}\text { Staf bagian Umum dan Kepegawaian cekatan dalam } \\
\text { menangani setiap usul berkas pelayanan administrasi } \\
\text { kepegawaian anda }\end{array}$ & 0,219 & 0,195 & Valid \\
\hline 3 & $\begin{array}{l}\text { Staf bagian Umum dan Kepegawaian memberikan perhatian } \\
\text { serius terhadap usul berkas Adimistrasi Anda }\end{array}$ & 0,295 & 0,195 & Valid \\
\hline 4 & $\begin{array}{l}\text { DayaTanggap (Responsiveness) } \\
\text { Saya tidak terlalu lama mengantri ketika akan mengajukan berkas } \\
\text { administrasi kepegawaian }\end{array}$ & 0,475 & 0,195 & Valid \\
\hline 5 & $\begin{array}{l}\text { Saya tidak terlalu lama menunggu hasil dari berkas yang saya } \\
\text { ajukan. }\end{array}$ & 0,260 & 0,195 & Valid \\
\hline 6 & $\begin{array}{l}\text { Staf bagian Umum dan Kepegawaian tidak membiarkan anda } \\
\text { berdiri lama ketika kursi tempat tunggu penuh }\end{array}$ & 0,234 & 0,195 & Valid \\
\hline 7 & $\begin{array}{l}\text { Ketika anda membutuhkan sesuatu Staf bagian Umum dan } \\
\text { Kepegawaian memiliki waktul uang untuk membantu anda }\end{array}$ & 0,301 & 0,195 & Valid \\
\hline & Jaminan Assurance) & & & \\
\hline 8 & $\begin{array}{l}\text { Staf bagian Umum dan Kepegawaian memiliki pengetahuan } \\
\text { tentang layanan administrasi kepegawaian yang anda usulkan }\end{array}$ & 0,269 & 0,195 & Valid \\
\hline
\end{tabular}




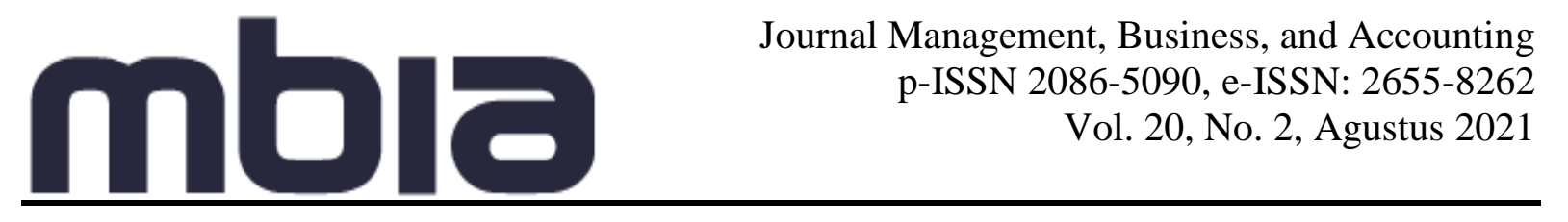

\begin{tabular}{|c|l|c|c|c|}
\hline 9 & $\begin{array}{l}\text { Staf bagian Umum dan Kepegawaian menjamin berkas yang } \\
\text { diusulkan akan cepat diproses }\end{array}$ & 0,351 & 0,195 & Valid \\
\hline 10 & $\begin{array}{l}\text { Pelayanan prima akan selalu anda terima setiap kali anda } \\
\text { berkunjung }\end{array}$ & 0,379 & 0,195 & Valid \\
\hline 11 & $\begin{array}{l}\text { Anda merasa aman dan nyaman pada saat berada di bagian umum } \\
\text { dan kepegawaian }\end{array}$ & 0,254 & 0,195 & Valid \\
\hline 12 & $\begin{array}{l}\text { Staf bagian Umum dan Kepegawaian bersikap sopan dan sabra } \\
\text { kepada anda }\end{array}$ & 0,203 & 0,195 & Valid \\
\hline & Empati (Empathy) & & & \\
\hline 13 & $\begin{array}{l}\text { Staf bagian Umum dan Kepegawaian memberikan perhatian } \\
\text { secara individual kepada anda }\end{array}$ & 0,451 & 0,195 & Valid \\
\hline 14 & $\begin{array}{l}\text { Staf bagian Umum dan Kepegawaian memiliki kesungguhan } \\
\text { dalam merespon pertanyaan dan keluhan anda }\end{array}$ & 0,413 & 0,195 & Valid \\
\hline 15 & $\begin{array}{l}\text { Staf bagian Umum dan Kepegawaian memberikan pelayanan } \\
\text { yang sama tanpa memandang status sosial }\end{array}$ & 0,352 & 0,195 & Valid \\
\hline 16 & $\begin{array}{l}\text { Rukti Fisik (Tangibles) } \\
\text { nyaman kantor Umum dan Kepegawaian memiliki tempat yang }\end{array}$ & 0,381 & 0,195 & Valid \\
\hline 17 & $\begin{array}{l}\text { Lokasi ruangan kantor Umum dan Kepegawaian mudah untuk } \\
\text { ditemukan }\end{array}$ & 0,283 & 0,195 & Valid \\
\hline 18 & $\begin{array}{l}\text { Ruangan kantor Umum dan Kepegawaian memiliki tata ruang } \\
\text { yang menarik }\end{array}$ & 0,323 & 0,195 & Valid \\
\hline 19 & $\begin{array}{l}\text { Fasilitas pelengkap yang disediakan kantor Umum dan } \\
\text { Kepegawaian (kursi,meja, wastafel, dll) bersih dan dalam } \\
\text { keadaan baik }\end{array}$ & 0,244 & 0,195 & Valid \\
\hline 20 & \begin{tabular}{l} 
Staf Umum dan Kepegawaian berpenampilan bersih dan rapih \\
\hline
\end{tabular} & 0,271 & 0,195 & Valid \\
\hline
\end{tabular}

Sumber: Hasil Pengolahan Data SPSS

Tabel 2. Tabel Uji Validasi Harapan Kualitas Layanan Administrasi Pendidikan

\begin{tabular}{|l|l|l|l|l|}
\hline No & \multicolumn{1}{|c|}{ Daftar Pertanyaan } & \multicolumn{1}{|c|}{$\mathrm{r}_{\text {hitung }}$} & $\mathrm{r}_{\text {tabel }}$ & Status \\
\hline 1 & \multicolumn{1}{|c|}{ Kehandalan (Reliability) } & & \\
\hline 2 & $\begin{array}{l}\text { Staf bagian Umum dan Kepegawaian memiliki kemampuan } \\
\text { memproses usul berkas layanan administrasi anda }\end{array}$ & 0,348 & 0,195 & Valid \\
\hline $\begin{array}{l}\text { Staf bagian Umum dan Kepegawaian cekatan dalam } \\
\text { menangani setiap usul berkas pelayanan administrasi } \\
\text { kepegawaian anda }\end{array}$ & 0,204 & 0,195 & Valid \\
\hline 3 & $\begin{array}{l}\text { Staf bagian Umum dan Kepegawaian memberikan perhatian } \\
\text { serius terhadap usul berkas Adimistrasi Anda }\end{array}$ & 0,289 & 0,195 & Valid \\
\hline & DayaTanggap (Responsiveness) & & & \\
\hline 4 & $\begin{array}{l}\text { Saya tidak terlalu lama mengantri ketika akan mengajukan berkas } \\
\text { administrasi kepegawaian }\end{array}$ & 0,360 & 0,195 & Valid \\
\hline 5 & $\begin{array}{l}\text { Saya tidak terlalu lama menunggu hasil dari berkas yang saya } \\
\text { ajukan. }\end{array}$ & 0,351 & 0,195 & Valid \\
\hline 6 & $\begin{array}{l}\text { Staf bagian Umum dan Kepegawaian tidak membiarkan anda } \\
\text { berdiri lama ketika kursi tempat tunggu penuh }\end{array}$ & 0,219 & 0,195 & Valid \\
\hline 7 & $\begin{array}{l}\text { Ketika anda membutuhkan sesuatu Staf bagian Umum dan } \\
\text { Kepegawaian memiliki waktu luang untuk membantu anda }\end{array}$ & 0,277 & 0,195 & Valid \\
\hline & Jaminan (Assurance) & & & \\
\hline 8 & $\begin{array}{l}\text { Staf bagian Umum dan Kepegawaian memiliki pengetahuan } \\
\text { tentang layanan administrasi kepegawaian yang anda usulkan }\end{array}$ & 0,246 & 0,195 & Valid \\
\hline
\end{tabular}




\begin{tabular}{|c|l|l|l|l|}
\hline 9 & $\begin{array}{l}\text { Staf bagian Umum dan Kepegawaian menjamin berkas yang } \\
\text { diusulkan akan cepat diproses }\end{array}$ & 0,238 & 0,195 & Valid \\
\hline 10 & $\begin{array}{l}\text { Pelayanan prima akan selalu anda terima setiap kali anda } \\
\text { berkunjung }\end{array}$ & 0,200 & 0,195 & Valid \\
\hline 11 & $\begin{array}{l}\text { Anda merasa aman dan nyaman pada saat berada di bagian umum } \\
\text { dan kepegawaian }\end{array}$ & 0,266 & 0,195 & Valid \\
\hline 12 & $\begin{array}{l}\text { Staf bagian Umum dan Kepegawaian bersikap sopan dan sabar } \\
\text { kepada anda }\end{array}$ & 0,257 & 0,195 & Valid \\
\hline & Empati (Empathy) & & & \\
\hline 13 & $\begin{array}{l}\text { Staf bagian Umum dan Kepegawaian memberikan perhatian } \\
\text { secara individual kepada anda }\end{array}$ & 0,273 & 0,195 & Valid \\
\hline 14 & $\begin{array}{l}\text { Staf bagian Umum dan Kepegawaian memiliki kesungguhan } \\
\text { dalam merespon pertanyaan dan keluhan anda }\end{array}$ & 0,359 & 0,195 & Valid \\
\hline 15 & $\begin{array}{l}\text { Staf bagian Umum dan Kepegawaian memberikan pelayanan } \\
\text { yang sama tanpa memandang status sosial }\end{array}$ & 0,323 & 0,195 & Valid \\
\hline & $\begin{array}{l}\text { Bukti Fisik (Tangibles) } \\
\text { Ruangan kantor Umum dan Kepegawaian memilikit empat yang } \\
\text { nyaman }\end{array}$ & 0,202 & 0,195 & Valid \\
\hline 17 & $\begin{array}{l}\text { Lokasi ruangan kantor Umum dan Kepegawaian mudah untuk } \\
\text { ditemukan }\end{array}$ & 0,205 & 0,195 & Valid \\
\hline 18 & $\begin{array}{l}\text { Ruangan kantor Umum dan Kepegawaian memiliki tata ruang } \\
\text { yang menarik }\end{array}$ & 0,208 & 0,195 & Valid \\
\hline 19 & $\begin{array}{l}\text { Fasilitas pelengkap yang disediakan kantor Umum dan } \\
\text { Kepegawaian (kursi, meja, wastafel, dll) bersih dan dalam } \\
\text { keadaanbaik }\end{array}$ & 0,419 & 0,195 & Valid \\
\hline 20 & \begin{tabular}{l} 
Staf Umum dan Kepegawaian berpenampilan bersih dan rapih \\
\hline
\end{tabular} & 0,203 & 0,195 & Valid \\
\hline
\end{tabular}

\section{Sumber: Hasil Pengolahan Data SPSS}

Dari hasil uji validitas terhadap butir-butir pertanyaan yang dijawab oleh responden untuk $\mathrm{r}_{\text {tabel }}$ dengan tingkat signifikansi 5\% dan jumlah data $(n)=100$, maka didapatkan $r_{\text {tabel }}$ sebessar .195 , jika $r_{\text {hitung }}>$ $\mathrm{r}_{\text {tabel }}$ maka butir pertanyaan dapat dinyatakan valid.

\subsection{Uji Reliabilitas Data}

Alat ukur dapat dikatakan reliabel jika alat tersebut dapat dipercaya, konsisten dan stabil. Uji reliabilitas dimaksudkan untuk mengetahui sejauh mana hasil pengukuran dapat konsisten, apabila dilakukan pengukuran dua kali atau lebih terhadap gejala yang sama dengan alat pengukuran yang sama pula.

Tinggi rendahnya reliabilitas, secara empirik ditunjukan oleh suatu angka yang disebut nilai koefisien reliabilitas. Reliabilitas yang tinggi ditunjukan dengan nilai rxx mendekati angka 1. Kesepakatan secara umum reliabilitas yang dianggap sudah cukup memuaskan jika $\geq 0.700$. Pengujian reliabilitas instrumen dengan menggunakan rumus Alpha Cronbach karena instrumen penelitian ini berbentuk angket dan skala bertingkat.

Jika nilai alpha $>0.7$ artinya reliabilitas mencukupi (sufficient reliability) sementara jika alpha $>0.80$ ini mensugestikan seluruh item reliabel dan seluruh tes secara konsisten memiliki reliabilitas yang kuat. Atau, ada pula yang memaknakannya sebagai berikut: Jika alpha $>0.90$ maka reliabilitas sempurna. Jika alpha antara $0.70-0.90$ maka reliabilitas tinggi. Jika alpha $0.50-0.70$ maka reliabilitas moderat. Jika alpha $<0.50$ maka reliabilitas rendah. Jika alpha rendah, kemungkinan satu atau beberapa item tidak reliabel.

Berdasarkan hasil pengolahan data menggunakan SPSS hasil uji reabilitas kuesioner adalah sebagai berikut : 
Tabel 3. Tabel Output Pertama Case Processing Summary Persepsi Kualitas Layanan

\begin{tabular}{|c|c|c|c|}
\hline \multicolumn{4}{|c|}{ Case Processing Summary } \\
\hline & & $\mathrm{N}$ & $\%$ \\
\hline \multirow[t]{3}{*}{ Cases } & Valid & 100 & 100 \\
\hline & Excluded $^{\mathrm{a}}$ & 0 & .0 \\
\hline & $1 \quad$ Tota & 100 & $\begin{array}{r}100 \\
.0\end{array}$ \\
\hline
\end{tabular}

a. Listwise deletion based on all variables in the procedure.

\section{Sumber : Hasil Pengolahan Data SPSS}

Dari output tabel di atas, memberikan informasi bahwa jumlah sampel atau responden yang dianalisis menggunakan SPSS sebanyak 100 orang. Karena tidak ada data yang kosong (jawaban responden terisi semua) maka jumlah valid adalah $100 \%$.

Tabel 4. Tabel Reliability Statistics Persepsi Kualitas Layanan

\begin{tabular}{|r|r|}
\hline \multicolumn{2}{|c|}{ Reliability Statistics } \\
\hline $\begin{array}{c}\text { Cronbach's } \\
\text { Alpha }\end{array}$ & N of Items \\
\hline .626 & 20 \\
\hline
\end{tabular}

\section{Sumber : Hasil Pengolahan Data SPSS}

Dari output table di atas, dapat diketahui $\mathrm{N}$ of items (banyaknya butir pertanyaan kuesioner) ada 20 buah item pertanyaan dengan nilai Cronbach's Alpha sebesar 0.626. karena nilai Cronbach's Alpha 0,626 berada di antara 0.50 - 0,70 maka dapat disimpulkan 20 pertanyaan kuesioner untuk nilai reliabelnya adalah moderat.Sehingga kuesioner ini dikatakan konsisten (reliabel).

Tabel 5. Tabel Item-Total Statisitcs Persepsi Kualitas Layanan

\begin{tabular}{|l|r|r|r|r|}
\hline \multicolumn{7}{|c|}{ Item-Total Statistics } \\
\hline & $\begin{array}{c}\text { Scale Mean if } \\
\text { Item Deleted }\end{array}$ & $\begin{array}{c}\text { Scale Variance } \\
\text { if Item Deleted }\end{array}$ & $\begin{array}{c}\text { Corrected } \\
\text { Item-Total } \\
\text { Correlation }\end{array}$ & $\begin{array}{c}\text { Cronbach's } \\
\text { Alpha if Item } \\
\text { Deleted }\end{array}$ \\
\hline Item_1 & 164.33 & 40.304 & .155 & .621 \\
\hline Item_2 & 164.78 & 40.396 & .145 & .622 \\
\hline Item_3 & 164.09 & 39.982 & .227 & .616 \\
\hline Item_4 & 164.61 & 37.614 & .380 & .598 \\
\hline Item_5 & 165.04 & 40.019 & .179 & .619 \\
\hline Item_6 & 164.96 & 39.998 & .136 & .622 \\
\hline Item_7 & 164.85 & 40.189 & .244 & .617 \\
\hline Item_8 & 164.45 & 41.361 & -.021 & .634 \\
\hline Item_9 & 164.40 & 39.111 & .263 & .611 \\
\hline Item_10 & 164.18 & 39.119 & .301 & .609 \\
\hline Item_11 & 164.78 & 39.870 & .159 & .620 \\
\hline Item_12 & 164.35 & 40.452 & .124 & .623 \\
\hline Item_13 & 164.56 & 38.006 & .359 & .601 \\
\hline Item_14 & 164.61 & 38.483 & .323 & .605 \\
\hline
\end{tabular}




\begin{tabular}{|l|l|l|l|r|}
\hline Item_15 & 164.60 & 39.253 & .270 & .611 \\
\hline Item_16 & 164.55 & 38.896 & .294 & .609 \\
\hline Item_17 & 164.56 & 40.572 & .098 & .625 \\
\hline Item_18 & 164.88 & 40.935 & .023 & .632 \\
\hline Item_19 & 164.78 & 40.961 & .215 & .622 \\
\hline Item_20 & 164.63 & 40.195 & .205 & .618 \\
\hline
\end{tabular}

Sumber : Hasil Pengolahan Data SPSS

Pada tabel ini memberikan gambaran nilai statistik untuk setiap item pertanyaan dari kuesioner. Maka dapat diketahui perubahan nilai Cronbach's Alpha dari kolom "Cronbach's Alpha if Item Deleted" untuk ke-20 item pertanyaan di atas berada di antara 0,5 - 0,7 maka dapat disimpulkan bahwa semua item pertanyaan dalam kuesioner tersebut moderat.

Tabel 6. Tabel Output Pertama Case Processing Summary Harapan Kualitas Layanan

\begin{tabular}{|l|l|r|r|}
\hline \multicolumn{3}{|c|}{ Case Processing Summary } \\
\hline \multirow{3}{*}{ Cases } & Valid & 100 & \multicolumn{1}{c|}{100.0} \\
\cline { 2 - 4 } & Excluded $^{\mathrm{a}}$ & 0 & .0 \\
\cline { 2 - 4 } & Total & 100 & 100.0 \\
\hline
\end{tabular}

a. Listwise deletion based on all variables in the procedure.

\section{Sumber : Hasil Pengolahan Data SPSS}

Berdasarkan tabel di atas, memberikan informasi bahwa jumlah sampel atau responden yang dianalisis menggunakan SPSS sebanyak 100 orang. Karena tidak ada data yang kosong (jawaban responden terisi semua) maka jumlah valid adalah $100 \%$.

Tabel 7. Tabel Reliability Statistics Harapan Kualitas Layanan

\begin{tabular}{|r|r|}
\hline \multicolumn{2}{|c|}{ Reliability Statistics } \\
\hline $\begin{array}{c}\text { Cronbach's } \\
\text { Alpha }\end{array}$ & N of Items \\
\hline .513 & 20 \\
\hline
\end{tabular}

\section{Sumber : Hasil Pengolahan Data SPSS}

Dari output table di atas, dapat diketahui $\mathrm{N}$ of items (banyaknya butir pertanyaan kuesioner) ada 20 buah item pertanyaan dengan nilai Cronbach's Alpha sebesar 0.513 . karena nilai Cronbach's Alpha 0,513 berada di antara 0.50 - 0,70 maka dapat disimpulkan 20 pertanyaan kuesioner untuk nilai reliabelnya adalah moderat.Sehingga kuesioner ini dikatakan konsisten (reliabel).

Tabel 8. Tabel Item-Total Statisitcs Harapan Kualitas Layanan

\begin{tabular}{|l|r|r|r|r|}
\hline \multicolumn{5}{|c|}{ Item-Total Statistics } \\
\hline & $\begin{array}{c}\text { Scale Mean if } \\
\text { Item Deleted }\end{array}$ & $\begin{array}{c}\text { Scale Variance } \\
\text { if Item Deleted }\end{array}$ & $\begin{array}{c}\text { Corrected } \\
\text { Item-Total } \\
\text { Correlation }\end{array}$ & $\begin{array}{c}\text { Cronbach's } \\
\text { Alpha if Item } \\
\text { Deleted }\end{array}$ \\
\hline Item_1 & 167.25 & 17.765 & .222 & .490 \\
\hline Item_2 & 167.18 & 18.553 & .083 & .511 \\
\hline Item_3 & 167.03 & 18.151 & .171 & .499 \\
\hline Item_4 & 166.64 & 18.152 & .279 & .491 \\
\hline Item_5 & 166.99 & 17.889 & .240 & .490 \\
\hline
\end{tabular}




\begin{tabular}{|l|r|r|r|r|}
\hline Item_6 & 167.23 & 19.431 & -.106 & .536 \\
\hline Item_7 & 167.31 & 18.256 & .167 & .500 \\
\hline Item_8 & 167.63 & 18.336 & .123 & .505 \\
\hline Item_9 & 166.88 & 18.369 & .115 & .506 \\
\hline Item_10 & 166.85 & 18.492 & .045 & .519 \\
\hline Item_11 & 167.44 & 19.138 & -.006 & .517 \\
\hline Item_12 & 167.38 & 19.167 & -.021 & .519 \\
\hline Item_13 & 167.21 & 18.713 & .060 & .513 \\
\hline Item_14 & 167.26 & 17.912 & .256 & .489 \\
\hline Item_15 & 167.36 & 18.940 & .023 & .516 \\
\hline Item_16 & 166.84 & 19.489 & -.117 & .535 \\
\hline Item_17 & 167.41 & 18.628 & .107 & .507 \\
\hline Item_18 & 167.06 & 18.522 & .084 & .511 \\
\hline Item_19 & 167.20 & 17.677 & .321 & .481 \\
\hline Item_20 & 167.32 & 18.644 & .107 & .507 \\
\hline
\end{tabular}

\section{Sumber : Hasil Pengolahan Data SPSS}

Pada tabel ini memberikan gambaran nilai statistik untuk setiap item pertanyaan dari kuesioner. Maka dapat diketahui perubahan nilai Cronbach's Alpha dari kolom "Cronbach's Alpha if Item Deleted" untuk ke-20 item pertanyaan terdapat mayoritas di atas berada di antara 0,5 - 0,7 maka dapat disimpulkan bahwa hampir semua item pertanyaan dalam kuesioner tersebut moderat, kecuali pada item pertanyaan no 1, 3, 4, 5, 14, dan 19 yang memiliki reliabilitas rendah. Secara keseluruhan, Nilai Cronbach's Alpha menunjukkan pada angka 0,626 pada angket persepsi kualitas layanan dan 0,513 pada angket harapan kualitas layanan. Maka reabilitas kuesioner yang digunakan adalah moderat. Dari hasil penelitian didapatkan GAP antara Persepsi dan Harapan terhadap kualitas Pelayanan Administrasi kepegawaian Dinas Pendidikan Provinsi Sumatera Selatan. Hasil perhitungan nilai GAP dapat dilihat pada tabel berikut:

Tabel 9. Tabel Nilai Gap Kualitas Layanan Administrasi kepegawaian

\begin{tabular}{|c|c|c|c|c|}
\hline No & Daftar Pertanyaan & Persepsi & Harapan & GAP \\
\hline & Kehandalan (Reliability) & & & \\
\hline 1 & $\begin{array}{l}\text { Staf bagian Umum dan Kepegawaian memiliki kemampuan } \\
\text { memproses usul berkas layanan administrasi anda }\end{array}$ & 4,49 & 4,21 & 0,28 \\
\hline 2 & $\begin{array}{l}\text { Staf bagian Umum dan } \\
\text { menangani setiap usul } \\
\text { kepegawaian anda }\end{array}$ & 4,04 & 4,28 & $-0,24$ \\
\hline \multirow[t]{2}{*}{3} & $\begin{array}{l}\text { Staf bagian Umum dan Kepegawaian memberikan perhatian } \\
\text { serius terhadap usul berkas Adimistrasi Anda }\end{array}$ & 4,73 & 4,43 & 0,30 \\
\hline & DayaTanggap (Responsiveness) & & & \\
\hline 4 & $\begin{array}{l}\text { Saya tidak terlalu lama mengantri ketika akan mengajukan } \\
\text { berkas administrasi kepegawaian }\end{array}$ & 4,21 & 4,82 & $-0,61$ \\
\hline 5 & $\begin{array}{l}\text { Saya tidak terlalu lama menunggu hasil dari berkas yang saya } \\
\text { ajukan. }\end{array}$ & 3,78 & 4,47 & $-0,69$ \\
\hline 6 & $\begin{array}{l}\text { Staf bagian Umum dan Kepegawaian tidak membiarkan } \\
\text { anda berdiri lama ketika kursi tempat tunggu penuh }\end{array}$ & 3,86 & 4,23 & $-0,37$ \\
\hline \multirow[t]{2}{*}{7} & $\begin{array}{l}\text { Ketika anda membutuhkan sesuatu Staf bagian Umum dan } \\
\text { Kepegawaian memiliki waktu luang untuk membantu anda }\end{array}$ & 3,97 & 4,15 & $-0,18$ \\
\hline & Jaminan (Assurance) & & & \\
\hline 8 & $\begin{array}{l}\text { Staf bagian Umum dan Kepegawaian memiliki pengetahuan } \\
\text { tentang layanan administrasi kepegawaian yang anda usulkan }\end{array}$ & 4,37 & 3,83 & 0,54 \\
\hline 9 & Staf bagian Umum dan Kepegawaian menjamin berkas yang & 4,42 & 4,58 & $-0,16$ \\
\hline
\end{tabular}




\begin{tabular}{|c|l|l|l|l|}
\hline & diusulkan akan cepat diproses & & & \\
\hline 10 & $\begin{array}{l}\text { Pelayanan prima akan selalu anda terima setiap kali anda } \\
\text { berkunjung }\end{array}$ & 4,64 & 4,61 & 0,03 \\
\hline 11 & $\begin{array}{l}\text { Anda merasa aman dan nyaman pada saat berada di bagian } \\
\text { umum dan kepegawaian }\end{array}$ & 4,04 & 4,02 & 0,02 \\
\hline 12 & $\begin{array}{l}\text { Staf bagian Umum dan Kepegawaian bersikap sopan dan sabar } \\
\text { kepada anda }\end{array}$ & 4,47 & 4,08 & 0,39 \\
\hline 13 & $\begin{array}{l}\text { Staf bagian Umum dan Kepegawaian memberikan perhatian } \\
\text { secara individual kepada anda }\end{array}$ & 4,26 & 4,25 & 0,01 \\
\hline 14 & $\begin{array}{l}\text { Staf bagian Umum dan Kepegawaian memiliki kesungguhan } \\
\text { dalam merespon pertanyaan dan keluhan anda }\end{array}$ & 4,21 & 4,20 & 0,01 \\
\hline 15 & $\begin{array}{l}\text { Staf bagian Umum dan Kepegawaian memberikan pelayanan } \\
\text { yang sama tanpa memandang status sosial }\end{array}$ & 4,22 & 4,10 & 0,12 \\
\hline 16 & $\begin{array}{l}\text { Ruangan kantor Umum dan Kepegawaian memiliki tempat yang } \\
\text { nyaman }\end{array}$ & 4,27 & 4,62 & $-0,35$ \\
\hline 17 & $\begin{array}{l}\text { Lokasi ruangan kantor Umum dan Kepegawaian mudah untuk } \\
\text { ditemukan }\end{array}$ & 4,26 & 4,05 & 0,21 \\
\hline 18 & $\begin{array}{l}\text { Ruangan kantor Umum dan Kepegawaian memiliki tata ruang } \\
\text { yang menarik }\end{array}$ & 3,94 & 4,40 & $-0,46$ \\
\hline 19 & $\begin{array}{l}\text { Fasilitas pelengkap yang disediakan kantor Umum dan } \\
\text { Kepegawaian (kursi,meja, wastafel, dll) bersih dan dalam } \\
\text { keadaan baik }\end{array}$ & 4,04 & 4,26 & $-0,22$ \\
\hline 20 & Staf Umum dan Kepegawaian berpenampilan bersih dan rapih & 4,19 & 4,14 & 0,05 \\
\hline
\end{tabular}

Sumber : Hasil Pengolahan Data SPSS

Adapun hasil perhitungan kualitas layanan Bagian Kepegawaian Dinas Pendidikan Provinsi Sumatera Selatan berdasarkan tiap dimensi adalah sebagai berikut:

Tabel 10. Tabel Kualitas Layanan Berdasarkan Tiap Dimensi

\begin{tabular}{|c|l|l|l|l|}
\hline No & Dimensi & Persepsi & Harapan & GAP \\
\hline 1 & Kehandalan (Reliability) & 4,14 & 4,29 & $-0,15$ \\
\hline 2 & DayaTanggap (Responsiveness) & 3,96 & 4,42 & $-0,46$ \\
\hline 3 & Jaminan (Assurance) & 4,39 & 4,22 & 0,16 \\
\hline 4 & Empati (Empathy) & 4,23 & 4,18 & 0,05 \\
\hline 5 & Bukti Fisik (Tangibles) & 4,42 & 4,31 & 0,11 \\
\hline & Rata-rata & $\mathbf{4 , 2 3}$ & $\mathbf{4 , 2 9}$ & $\mathbf{- 0 , 0 6}$ \\
\hline
\end{tabular}

Sumber : Hasil Pengolahan Data SPSS

Dari tabel di atas, dapat diketahui bahwa rata-rata GAP antara persepsi kualitas layanan dan harapan kualitas layanan masih bernilai negatif $-0,06$ terutama pada dimensi daya tanggap dengan nilai negatif $-0,46$ dan dimensi kehandalan dengan nilai negatif $-0,15$ maka pelayanan di Bagian Kepegawaian Dinas Pendidikan Provinsi Sumatera Selatan memerlukan perbaikan dan peningkatan kualitas layanan. Dalam penelitian ini, dimensi-dimensi yang terkait dalam kualitas layanan suatu perusahaan adalah dimensi fisik (Tangible), dimensi kehandalan (Reliability), dimensi daya tanggap (Responsiveness), dimensi jaminan (Assurance), dan dimensi empati (Empathy). Kelima dimensi tersebut memiliki atribut-atribut di tiap dimensinya dan pada penelitian ini terdapat total 20 atribut pertanyaan yang diajukan kepada responden yaitu pendidik dan tenaga kependidikan yang mengurus berkas administrasi kepegawaian di Dinas Pendidikan Provinsi Sumatera Selatan. 
Berdasarkan hasil uji validitas dan reliabiltas kuesioner yang dibagikan kepada responden, dinyatakan bahwa keseluruhan data dari responden valid, sehingga bisa digunakan dalam perhitungan Servqual. Analisis Servqual dilakukan dengan melihat kesenjangan (GAP) yang terjadi antara pelayanan yang diterima dengan kualitas pelayanan yang diharapkan oleh guru dan tenaga kependidikan. Terjadinya kesenjangan karena adanya gap yang bernilai negatif. Semakin kecil nilai gap maka semakin sedikit kesenjangan yang terjadi, artinya pelayanan yang diberikan semakin mendekati harapan pelanggan. Sedangkan jika gap bernilai positif, maka tidak ada kesenjangan yang terjadi. Semakin besar nilai gap berarti semakin tinggi tingkat kepuasan pelanggan.

\subsection{Dimensi Kehandalan (Reliability)}

Hasil penelitian pada dimensi kehandalan dapat digambarkan dalam bentuk diagram sebagai berikut :

Gambar 2. Diagram Dimensi Kehandalan (Reliability)

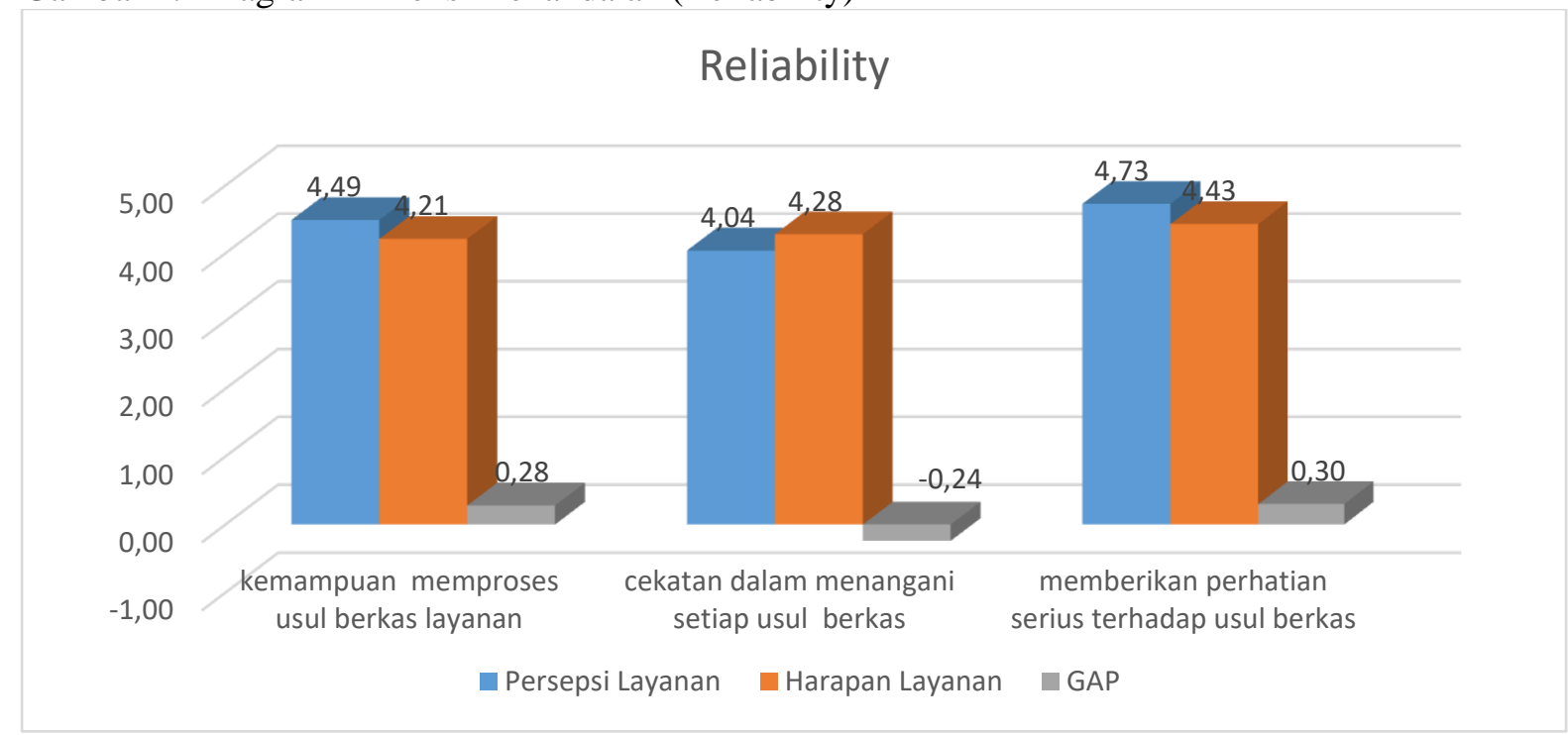

\section{Sumber : Data Primer, Data Diolah}

Terdapat 2 pertanyaan pada dimensi kehandalan yang menunjukan hasil yang positif yaitu kemampuan memproses berkas usulan layanan dengan nilai gap 0,28 dan memberikan perhatian serius terhadap usul berkas dengan nilai gap 0,30. Namun terdapat juga hasil yang masih negatif yaitu cekatan dalam menangani setiap usul berkas dengan nilai gap -0,24. Hal ini menunjukkan bahwa masih terdapat masalah kualitas layanan dalam dimensi kehandalan, yaitu kurang cekatan dalam menangani setiap usul berkas.

\subsection{Dimensi Daya Tanggap (Responsiveness)}

Pada dimensi daya tanggap, terdapat 4 pertanyaan yang bernilai negatif yang artinya secara keseluruhan masih memerlukan perbaikan peningkatan kualitas layanan. Yang paling bernilai negatif dan mendesak untuk dilakukan perbaikanya itu tidak terlalu lama menunggu hasil dari berkas dengan nilai gap -0,69 disusul dengan tidak terlalu lama mengantri ketika akan mengajukan berkas dengan nilai gap $-0,61$. Selanjutnya perlu dilakukan perbaikan pada pertanyaan tidak membiarkan berdiri lama dengan nilai gap $-0,37$ dan memiliki waktu luang untuk membantu dengan nilai gap $-0,18$.

Hasil penelitian pada dimensi daya tanggap dapat digambarkan dalam bentuk diagram sebagai berikut : 
Gambar 3. Diagram Daya Tanggap (Responsiveness)

\section{Responsive}

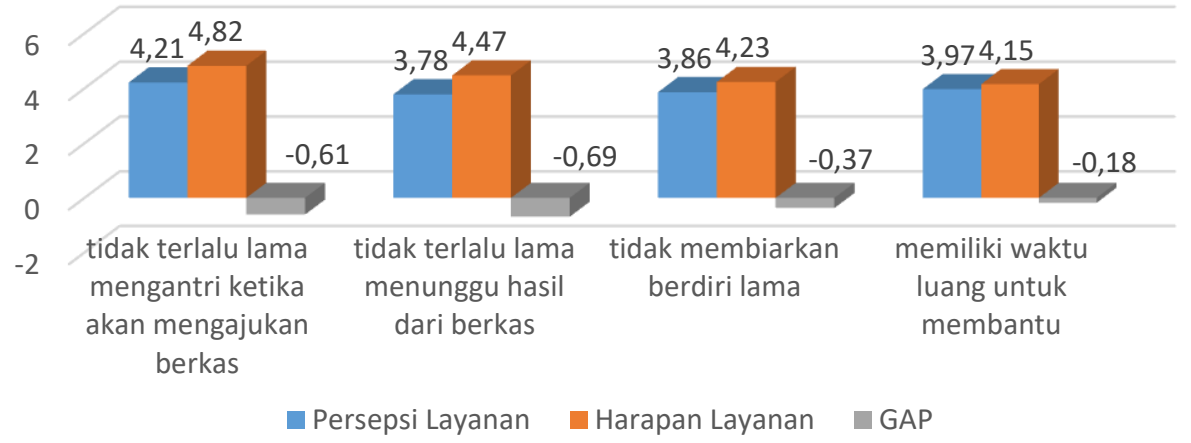

\section{Sumber : Data Primer, Data Diolah}

\subsection{Dimensi Jaminan (Assurance)}

Hasil penelitian pada dimensi jaminan dapat digambarkan dalam bentuk diagram sebagai berikut :

Gambar 4 Diagram Dimensi Jaminan (Assurance)

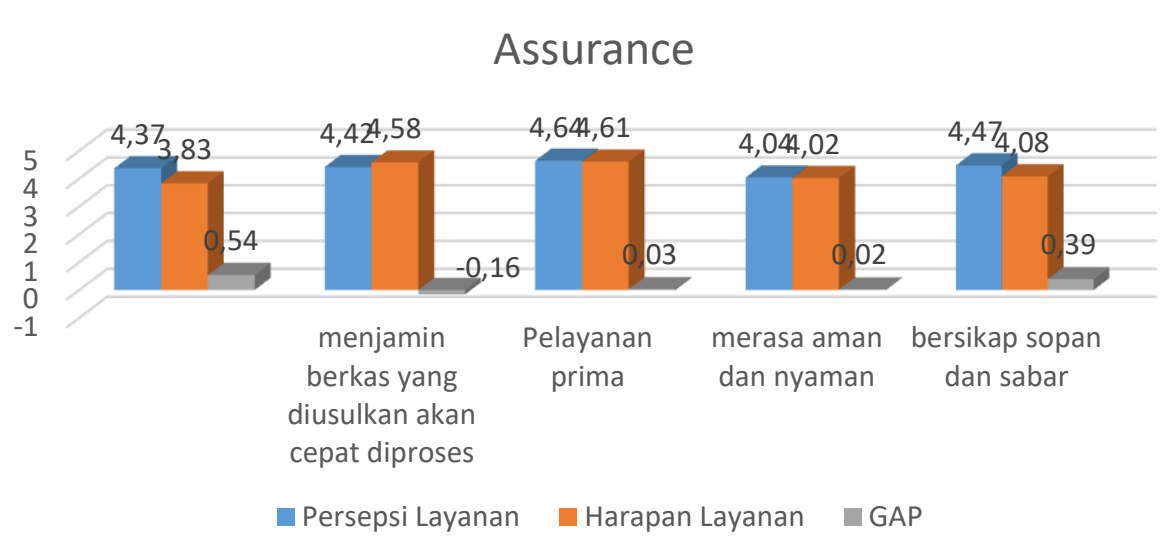

\section{Sumber : Data Primer, Data Diolah}

Sebagian besar pertanyaan pada dimensi jaminan menunjukkan nilai positif dengan nilai gap positf tertinggi pada pertanyaan memiliki pengetahuan tentang layanana dministrasi kepegawaian yaitu 0,54. Selanjutnya pegawai Sub Bidang Kepegawaian Dinas Pendidikan Provinsi Sumatera Selatan dianggap bersikap sopan dan sabar, hal ini dapat dlihat dari nilai gap positif sebesar 0,39. Mampu memberikan pelayanan prima dengan nilai gap positif 0,03 serta membuat guru merasa aman dan nyaman dalam melakukan pengajuan berkas kepegawaian dengan nilai gap positif 0,02 . Namun masih perlu dilakukan perbaikan dalam menjamin berkas yang diusulkan akan cepat diproses dengan nilai negatif $-0,16$.

\subsection{Dimensi Empati (Empathy)}

Dimensi empati secara keseluruhan bernilai positif dengan nilai tertinggi terdapat pada memberikan pelayanan yang sama. Dan nilai terendah positif terdapat pada dua pertanyaan yaitu memberikan perhatian secara individual dan memiliki kesungguhan dalam merespon pertanyaan dengan masingmasing nilai gap positif 0,01 . 
Hasil penelitian pada dimensi empati dapat digambarkan dalam bentuk diagram sebagai berikut :

Gambar 5. Diagram Dimensi Empati

Empathy

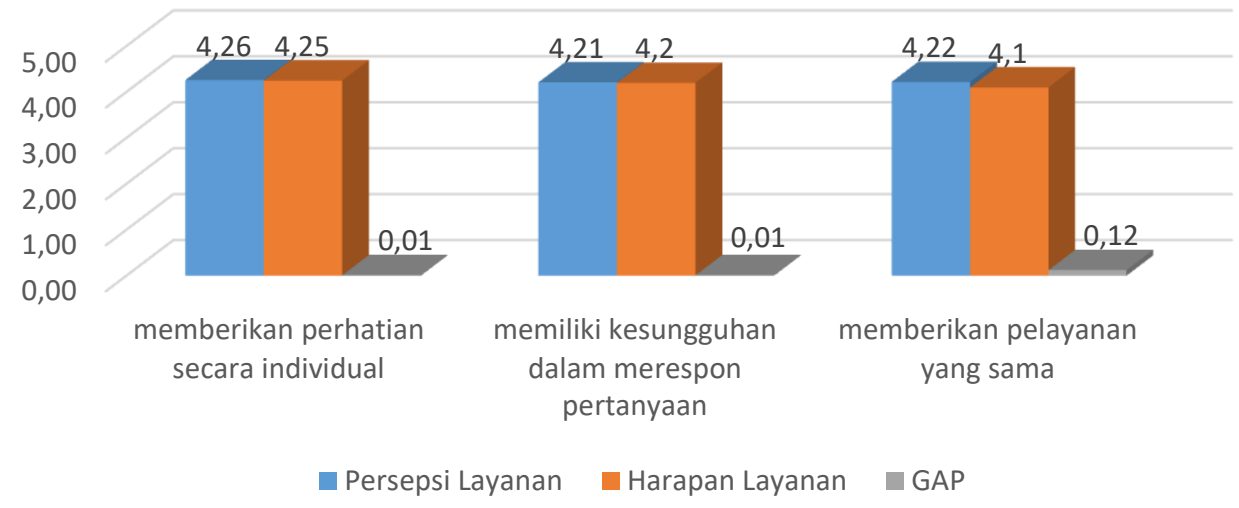

Sumber : Data Primer, Data Diolah

4.7. Dimensi Bukti Fisik (Tangible)

Hasil penelitian pada dimensi bukti fisik dapat digambarkan dalam bentuk diagram sebagai berikut :

Gambar 6. Diagram Dimensi Bukti Fisik (Tangible)

\section{Chart Title}

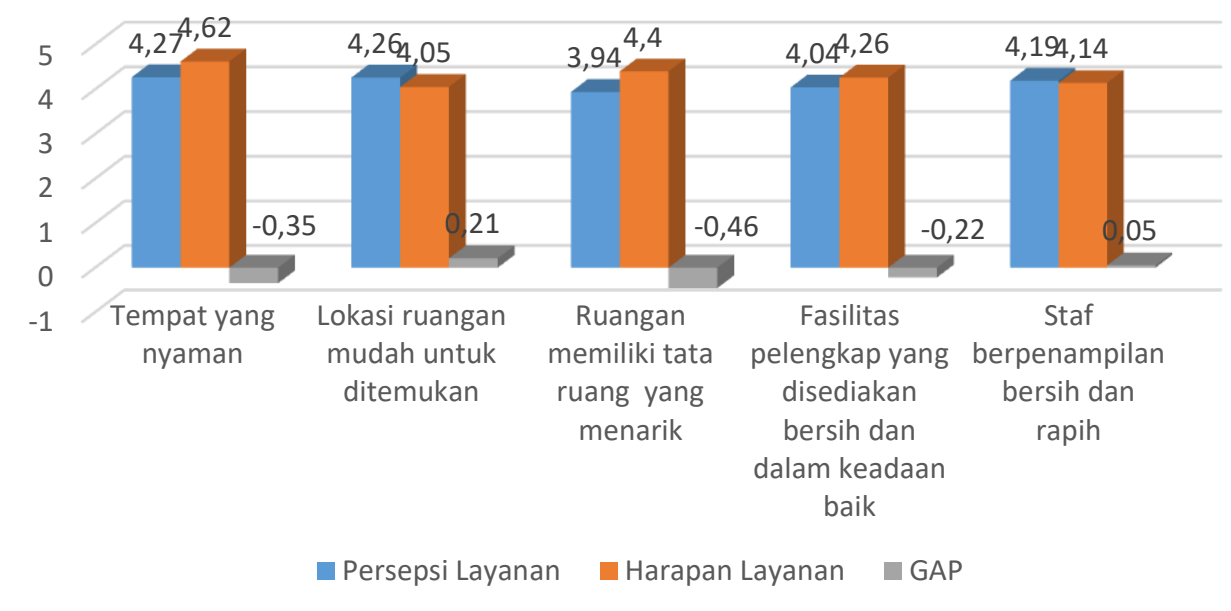

\section{Sumber : Data Primer, Data Diolah}

Terdapat 3 pertanyaan bernilai negative dan 2 pertanyaan bernilai positif pada dimensi bukti fisik. Nilai negatif tertinggi terdapat pada ruangan memiliki tata ruang yang menarik dengan nilai $-0,46$. Nilai negatif terendah terdapat pada fasilitas pelengkap yang disediakan bersih dan dalam keadaan baik dengan nilai gap $-0,22$. Pertanyaan yang bernilai positif terdapat pada lokasi ruangan mudah ditemukan dengan nilai gap 0,21 .

\subsection{Analisis Fishbone}

Dari hasil penelitian didapatkan data bahwa GAP yang bernilai negatif adalah sebagai berikut :

1. Dimensi Keandalan (Realibility): 
- Nilai GAP -0,24 untuk pertanyaan cekatan dalam menangani setiap ususl berkas;

2. Dimensi Daya Tanggap (Responsieveness):

- Nilai GAP -0,61 untuk pertanyaan tidak terlalu lama mengantri ketika akan mengajukan berkas;

- Nilai GAP -0,69 untuk pertanyaan tidak terlalu lama menunggu hasil dari usulan berkas;

- Nilai GAP -0,37 untuk pertanyaan tidak membiarkan berdiri lama;

- Nilai GAP -0,18 untuk pertanyaan waktu luang untuk membantu;

3. Dimensi Jaminan (Assurance):

- Nilai GAP -0,16 untuk pertanyaan menjamin berkas yang diusulkan akan cepat diproses.

4. Dimensi Bukti Fisik (Tangible):

- Nilai GAP -0,35 untuk pertanyaan tempat yang nyaman;

- Nilai GAP -0,46 untuk tata ruang yang menarik;

- Nilai GAP -0,22 untuk pertanyaan fasilitas pelengkap yang disediakan bersih dan dalam keadaan baik.

Setelah mendapatkan GAP yang bernilai negatif maka GAP itu dikelompokan ke dalam diagram Tulang Ikan (Fishbone Chart). Menurut Immamoto (Fauziah : 2009) "Analisa Tulang Ikan dipakai untuk mengkategorikan berbagai sebab potensial dari satu masalah atau pokok persoalan dengan mudah dimengerti dan rapi. Alat ini membantu kita menganalisis masalah yang terjadi di dalam suatu proses yaitu dengan cara memecah proses menjadi sejumlah kategori yang berkaitan dengan proses mencakup manusia, material, mesin, prosedur, kebijakan dan sebagainya. GAP yang bernilai negatif kemudian ditetapkan sebagai kategori utama pada cabang- cabang utama yang membentuk tulangtulang besar pada Diagram Fishbone. Kemudian tetapkan penyebab dalam kategori utama yang akan ditempatkan di tulang-tulang kecil Diagram Fishbone" Untuk setiap penyebab yang mungkin, tanyakan "mengapa" untuk menemukan akar penyebab masalah. Untuk menemukan akar penyebab masalah kita dapat menggunakan teknik bertanya 5W dan 1H (Metode Kaizen). Dari GAP yang bernilai negatif dapat kita Identifikasi masalah Kualitas Layanan Administrasi Kepegawaian sebagai berikut :

Tabel 11. 5W dan $1 \mathrm{H}$

\begin{tabular}{|c|l|}
\hline No & \multicolumn{1}{|c|}{ Why / Penyebab } \\
\hline \multirow{2}{*}{1} & $\begin{array}{l}\text { Perlu dilakukan pemeriksaan terhadap kelengkapan berkas yang dibutuhkan sebagai syarat } \\
\text { pelayanan; }\end{array}$ \\
\cline { 2 - 3 } & Jumlah Usul Berkas yang masuk untuk diproses sangat banyak \\
\hline \multirow{2}{*}{2} & Luas Ruangan yang terbatas; \\
\cline { 2 - 3 } & AC tidak dingin \\
\hline \multirow{2}{*}{3} & Terlalu banyak meja \\
\cline { 2 - 3 } & Tidak ada ruang khusus untuk melakukan pelayanan \\
\hline \multirow{2}{*}{4} & Keadaan WC masih bau \\
\cline { 2 - 3 } & Taman kurang bersih \\
\cline { 2 - 3 } & Tempat parkir masih kurang bersih. \\
\hline 5 & Proses pelayanan tidak bisa selesai dalam satu hari \\
\hline \multirow{2}{*}{6} & Tidak tersedianya kursi tambahan \\
\cline { 2 - 3 } & Tidak ada ruang tunggu \\
\hline 7 & Petugas yang melayani per kabupaten/kota hanya 1 orang \\
\hline \multirow{2}{*}{8} & Beberapa staf pegawai masih belum mahir menggunakan komputer, \\
\cline { 2 - 3 } & Kebanyakan Staf Umum dan Kepegawaian sudah tua \\
\hline 9 & Terlalu banyak berkas yang harus diproses untuk diselesaikan \\
\hline
\end{tabular}




\begin{tabular}{|c|l|}
\hline No & \multicolumn{1}{|c|}{ What / Masalah } \\
\hline 1 & Berkas yang diusulkan belum cepat diproses \\
\hline 2 & Ruang kurang nyaman \\
\hline 3 & Tata letak ruang kurang menarik \\
\hline 4 & Fasilitas kurang bersih \\
\hline 5 & Lama menunggu hasil \\
\hline 6 & Membiarkan berdiri lama ketika kursi tempat duduk penuh \\
\hline 7 & Lama mengantri \\
\hline 8 & Kurang cekatan \\
\hline 9 & Tidak memiliki waktu luang untuk membantu \\
\hline No & \\
\hline 1 & $\begin{array}{l}\text { Membuat database kepegawaian sehingga berkas yang dibutuhkan selalu tersimpan dalam } \\
\text { bentuk software dan mudah melakukan pemeriksaan kelengkapan syarat pelayanan }\end{array}$ \\
\hline \multirow{2}{*}{2} & Memperluas ruang staf \\
\cline { 2 - 3 } & Menambah jumlah AC \\
\hline \multirow{2}{*}{3} & $\begin{array}{l}\text { Membuat penataan ruang agar terkesan luas dan berkas yang tidak menumpuk di meja } \\
\text { pegawai. }\end{array}$ \\
\cline { 2 - 3 } & Membuat ruang khusu suntuk pelayanan guru, misalnya ruang khusus pelayanan satu pintu \\
\hline \multirow{2}{*}{4} & $\begin{array}{l}\text { Meningkatkan intensitas kegiatan pembersihan fasilitas dari 1 x (pagi) sehari menjadi 3x } \\
\text { sehari (pagi,siang, sore). }\end{array}$ \\
\cline { 2 - 3 } & Membuat wastafel di WC dan beberapa tempat lainnya. \\
\cline { 2 - 3 } & Menambah jumlah kotak sampah \\
\hline 5 & Mempercepat proses pelayanan dengan membuat standar waktu pelayanan per berkas \\
\hline \multirow{2}{*}{6} & Menambah jumlah kursi \\
\cline { 2 - 3 } & Membuat ruang tunggu \\
\hline 7 & Menambah jumlah petugas dalam melakukan pelayanan per kabupaten/kota \\
\cline { 2 - 3 } & Mengkaderisasi Staf yang masih muda \\
\hline 9 & Menambah jumlah pegawai \\
\hline \multirow{2}{*}{ tumban pelatihan peningkatan kompetensi pegawai baik secara kolektif maupun } \\
\hline
\end{tabular}

Sumber : Data Primer, Data Diolah

Setelah didapatkan akar masalahnya maka diagram Fishbone Kualitas Administrasi Kepegawaian Dinas Pendidikan Provinsi Sumatera Selatan dapat digambarkan sebagai berikut:

Setelah didapatkan akar penyebab masalah selanjutnya adalah bagaimana mengatasi masalah tersebut untuk menuju proses perbaikan kualitas pelayanan. Pertanyaan berikutnya dalam Metode Kaizen adalah Who, When, Where yang akan menjadi objek perbaikan kualitas pelayanan untuk mengatasi GAP yang terjadi pada kualitas pelayanan. 
Gambar 7. Diagram Fishbone kualitas layanan

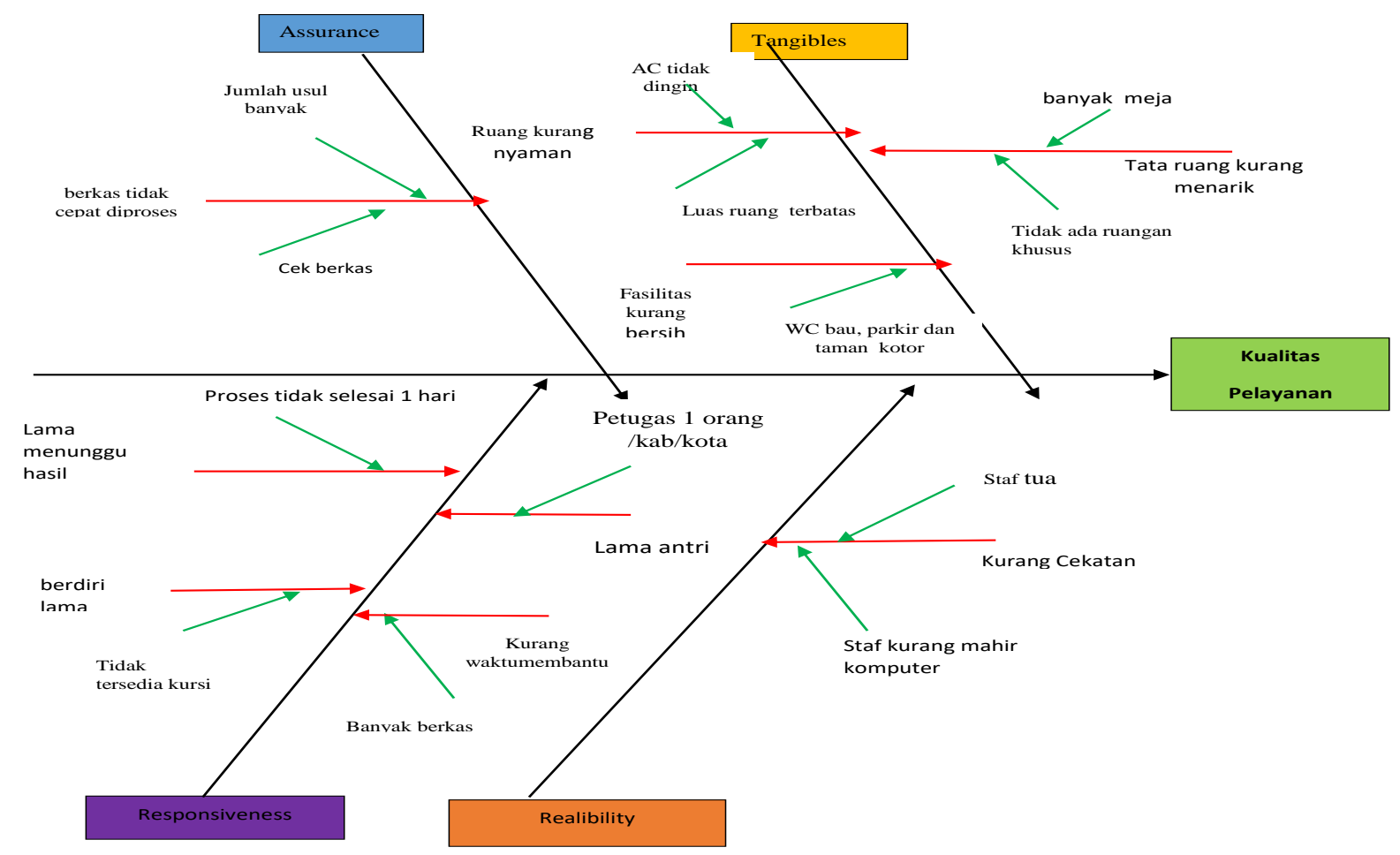

Sumber : Data Primer, Data Diolah

Tabel 12. Lanjutan $5 \mathrm{~W} 1 \mathrm{H}$

\begin{tabular}{|l|l|l|l|}
\hline \multirow{2}{*}{ No } & Who & When & Where \\
\cline { 2 - 4 } & Pelaku & Kapan & Dimana \\
\hline 1 & $\begin{array}{l}\text { Staf Sub } \\
\text { Kepegawaian }\end{array}$ & Perbaikan dilakukan secepatnya & Ruang Sub Kepegawaian \\
\hline 2 & $\begin{array}{l}\text { Kepala Dinas } \\
\text { Pendidikan }\end{array}$ & Perbaikan dilakukan secepatnya & Ruang Sub Kepegawaian \\
\hline 3 & $\begin{array}{l}\text { Sekretaris Dinas } \\
\text { Pendidikan }\end{array}$ & Perbaikan dilakukan secepatnya & Ruang Sub Kepegawaian \\
\hline 4 & $\begin{array}{l}\text { Staf Kebersihan } \\
\text { Dinas Pendidikan }\end{array}$ & $\begin{array}{l}\text { Perbaikan dilakukans ecepatnya dan } \\
\text { dilakukan pengecekan secara berkala }\end{array}$ & $\begin{array}{l}\text { WC, Ruang Sirkulasi, } \\
\text { TempatParkir, Taman }\end{array}$ \\
\hline 5 & $\begin{array}{l}\text { Kasubbag } \\
\text { Kepegawaian }\end{array}$ & $\begin{array}{l}\text { Perbaikan dilakukan secepatnya dan } \\
\text { dilakukan pengecekan secara berkala }\end{array}$ & Ruang Sub Kepegawaian \\
\hline 6 & $\begin{array}{l}\text { Sekretaris Dinas } \\
\text { Pendidikan }\end{array}$ & $\begin{array}{l}\text { Perbaikan dilakukan secepatnya dan } \\
\text { dilakukan pengecekan secara berkala }\end{array}$ & Ruang Sub Kepegawaian \\
\hline 7 & $\begin{array}{l}\text { Kepala Dinas } \\
\text { Pendidikan }\end{array}$ & $\begin{array}{l}\text { Perbaikan dilakukan secepatnya dan } \\
\text { dilakukan pengecekan secara berkala }\end{array}$ & Ruang Sub Kepegawaian \\
\hline 8 & $\begin{array}{l}\text { Kasubbag } \\
\text { Kepegawaian } \\
\text { Dinas Pendidikan }\end{array}$ & $\begin{array}{l}\text { Perbaikan dilakukan secepatnya dan } \\
\text { dilakukan pengecekan secara berkala }\end{array}$ & Ruang Sub Kepegawaian \\
\hline 9 & $\begin{array}{l}\text { Kepala Dinas } \\
\text { Pendidikan }\end{array}$ & Perbaikan dilakukan secepatnya & Ruang Sub Kepegawaian \\
\hline
\end{tabular}

Sumber : Data Primer, Data Diolah 


\section{Simpulan}

Berdasarkan penelitian yang telah dilakukan, maka dapat disimpulkan bahwa kualitas pelayanan administrasi kepegawaian yang dipersepsikan oleh Tenaga Pendidik dan Tenaga Kependidikan Dinas Pendidikan Provinsi Sumatera Selatan dalam lima dimensi kualitas layanan dari kualitas pelayanan (reliability, responsiveness, assurance, emphaty,and tangible) masuk kategori baik. Dari hasil pengijian menggunakan metode SERVQUAL (Service Quality) terjadi kesenjangan atau GAP dalam kualitas layanan yang diberikan oleh sub bagian Umum dan Kepegawaian karena ekpetasi (harapan) layanan lebih tinggi dari pada yang dipersepsikan artinya layanan belum bisa memuaskan para Tenaga

Pendidik dan Tenaga Kependidikan. Ada 9 atribut layanan administrasi kepegawaian yang bernilai negatif dan memerlukan prioritas perbaikan. Kualitas pelayanan administrasi kepegawaian yang baik akan semakin meneguhkan posisi srategis Dinas Pendidikan Provinsi Sumatera Selatan sebagai rujukan dalam sektor Pendidikan di Provinsi Sumatera Selatan. Strategi peningkatan kualitas layanan berdasarkan analisis kesenjangan atau GAP antara ekpektasi dan persepsi Tenaga Pendidik dan Tenaga Kependidikan adalah dengan melakukan perbaikan pada dimensi memiliki atribut nilai GAP negatif yaitu dengan perbaikan sarana dan prasarana dan peningkatan kualitas dan kuantitas SDM.

\section{Daftar Pustaka}

Fauziah, Naily, 2009, Aplikasi Fishbone Analysis Dalam Meningkatkan Kualitas Produksi Teh Pada PT.Rumpun Sari Kemuning, Kabupaten Karang Anyar, Fakultas Pertanian Universitas Sebelas Maret, Surakarta.

Ferdinand, Augusty. 2014, Metode Penelitian Manajemen, Pedoman Penelitian Untuk Penulisan Skripsi, Tesis dan Disertasi Ilmu Manajemen,Semarang, Penerbit Badan Penerbit Fakultas ekonomika dan Bisnis Universitas Diponegoro.

Nurdin, Ismail, 2019, Kualitas Pelayanan Publik, Surabaya, Penerbit MSC.

Peraturan Gubernur Sumatera Selatan Nomor 52 Tahun 2016 Tentang Susunan Organisasi, Uraian Tugas dan Fungsi Dinas Pendidikan Provinsi Sumatera Selatan.

Renstra 2019-2024, Bagian Perencanaan, Sekretariat, Dinas Pendidikan Provinsi Sumatera Selatan, 2019.

Rodiyah, Kholipatun Isnaini, 2014, Kualitas Pelayanan Administrasi Pendidikan di UPTD Dinas Pendidikan Kecamatan Porong Kabupaten Siduarjo, JKMP (ISSN. 2338-445X), Vol. 2, No. 2, September 2014, 103-220.

Semil, Nurmah. 2018, Pelayanan Prima Instansi Pemerintah, Kajian Kritis pada sistem Pelayanan Publik di Indonesia, Depok, Penerbit Prenamedia Group.

Sugiyono, 2016, Metode Penelitian Kuantitatif Kualitatif dan R\&D, Bandung, Penerbit Alfabeta.

Tjiptono, Fandy. 2017, Service Management Mewujudkan layanan Prima, Yogyakarta, Penerbit Andi.

Undang - Undang Republik Indonesia Nomor 23 Tahun 2014 Tentang Pemerintah Daerah.

\section{Copyright Disclaimer}

Copyright for this article is retained by the author(s), with first publication rights granted to the journal. 